\title{
Schatgraven in 'de mijnen van het Oosten'; Europa's eerste tijdschrift voor oriëntaalse studies
}

\author{
PETER RIETBERGEN
}

Tussen 1809 en I8I8 verscheen Fundgruben des Orients. Dit eerste Europese tijdschrift voor oriëntaalse studies was een spreekbuis voor liefhebbers van de cultuur van het Oosten. De redactie wilde de nadruk leggen op het Nabije Oosten. De groeiende koloniale invloed van Engeland in Azië, met name in India, weerspiegelde zich echter ook in de kolommen van het tijdschrift. Een politiek gevoelig artikel maakte waarschijnlijk een einde aan het blad.

'Gottes ist der Orient, Gottes ist der Occident. Er leitet, wen er will, den weiten Pfad.' Met dit religieus-morele motto ontleend aan Paulus' tweede Brief aan de Christenen van Corinthe kondigde een 'Gesellschaft von Liebhabern' in 1809 de verschijning aan van het tijdschrift Fundgruben des Orients. Dit periodiek was het eerste dat zich in Europa exclusief bezighield met de wereld van het Oosten, met Azië. ${ }^{3}$

Het motto van het tijdschrift confronteerde de lezer met het gegeven dat vanuit Gods perspectief de wereld één was en niet, zoals voor veel Europeanen, verdeeld in 'beschaafd' en 'onbeschaafd': God bepaalt de weg van de mens, van alle mensen, die voor hem gelijk zijn. Volgens de redactie van het blad, die in Wenen zetelde, kon het Westen in het Oosten nog allerlei belangrijks vinden. Daar kon het schatten delven. De ondertitel van het tijdschrift luidde dan ook Mines d'Orient. Deze bijdrage beoogt na te gaan wat de achtergronden van dit tijdschrift geweest zijn, wie de initiatiefnemers en auteurs waren, welk lezerspubliek hun voor ogen stond en, tenslotte, welke inhoudelijke bijdrage het tijdschrift gerealiseerd heeft.

In de eerste aflevering van Fundgruben des Orients bevindt zich een lange intentieverklaring, waarin de initiatiefnemers - die vooralsnog anoniem blijven - de beoogde lezers laten weten waarom zij het tijdschrift hebben opgericht. In deze inleiding wordt geschetst hoe de westerse en de oosterse wereld al in de Middeleeuwen met elkaar in contact kwamen, via de islamitische verovering van Spanje en de Kruistochten. De redactie van het tijdschrift laat er geen twijfel over bestaan welke regio de meer gecultiveerde was. De 'Genius des Orients' bracht het licht dat nodig was om de duisternis van de gotische barbarij te doorbreken, om de 'rauwe noordelijke zeden' te beschaven.

Op den duur leidde de kennismaking van Europa met Azië ook tot de oriëntaalse studies, die volgens de redactie essentieel waren voor de vroege ontwikkeling van de Europese wetenschappen en religies. Die studie werd beoefend in Engeland en 'Holland', in Italië en Spanje, in Frankrijk en de Duitse landen, maar ook in Oostenrijk en eveneens in het Osmaanse Rijk. Opmerkelijk is dat de redactie signaleert dat er sprake is van wetenschappelijke concurrentie in het veld van de oriëntaalse studies, 
niet tussen individuele wetenschappers maar tussen de landen waar de oriëntaalse studies beoefend worden.

De redactie constateert eveneens dat er nog te weinig wetenschappers zijn die de Oost bestuderen. Bovendien, en nog belangrijker, zou het niveau van de wetenschap achterblijven bij de studie naar de Grieks-Romeinse cultuur. Gebrek aan geld zou daarvan de belangrijkste oorzaak zijn. Wie belangrijke basisteksten op dit terrein wil uitgeven, vindt geen uitgevers. En het communicatiemedium bij uitstek, het tijdschrift, heeft op dit gebied nog geen plaats verworven. Eerdere initiatieven mislukten snel door gebrek aan mecenassen. Klaproths Asiatisches Magasin ${ }^{2}$ hield het nog geen jaar vol. Daarom kan het ook geen aanspraak maken op de eer het eerste tijdschrift voor oriëntaalse studies geweest te zijn. Ousely's Collections, niet een echt periodiek, deed het niet beter.

Dat Fundgruben des Orients wel van de grond kwam, was te danken aan een kleine groep liefhebbers en kenners van de oosterse cultuur en een grote mecenas, graaf Wenzel von Rzewusky (1765-1832). ${ }^{3}$ Overigens was Rzewusky geen redacteur. De financiële hulp van deze Poolse graaf stelde de redactie in staat een tijdschrift te produceren. Aanvankelijk was het de bedoeling dat er in vier afleveringen, in twintig katernen, zo'n driehonderd pagina's per jaar zouden verschijnen. In totaal verschenen er in zes jaargangen zo'n drieduizend pagina's.

De redactie van het tijdschrift wil alles publiceren dat de studie van het Morgenland betreft. Hoewel de meeste initiatiefnemers afkomstig zijn uit het Duitse taalgebied, kunnen de bijdragen in de meest gangbare Europese talen worden afgedrukt. Daarmee wordt verondersteld dat de geïnteresseerden in dit soort studies beschikken over kennis van het Frans, Italiaans, Engels, Spaans en Latijn.

De redactie, die verder anoniem blijft, laat verder weten te zetelen in Wenen en Constantinopel. Zij verwacht bijdragen uit heel Europa en acht dat mogelijk omdat zij over een net van correspondenten beschikt dat zich uitstrekt van Constantinopel tot de havens van de Levant, van Syrië en Egypte tot Perzië. Zij hoopt ook contacten te leggen met lieden die weet hebben van, of werkzaam zijn in Barbarije (Noord-Afrika), in Tartarije (Russisch-Azië), Armenië en Mongolië (de rest van Centraal-Azië), India en China. Het is verklaarbaar dat Japan helemaal niet genoemd wordt. Afgezien van de bewoners van de Nederlandse vestiging op Deshima, had geen enkele westerling toegang tot het Rijk van de Rijzende Zon. Bovendien waren door de oorlogstoestand in Europa zelfs de contacten tussen Deshima - via Batavia - en het moederland juist in deze periode bepaald problematisch.

De redactie benadrukt met name de betekenis van Wenen en Constantinopel voor de oriëntaalse studies. De keizerlijke bibliotheek en diverse privé-collecties in Wenen zijn vindplaatsen van onschatbaar materiaal. Met name wordt de collectie-Rzewusky genoemd, de geldschieter van het tijdschrift. Deze is bovendien verrijkt met de aankoop van de collecties-Jenisch en Wallenburg. Verder bestond in Wenen al in de achttiende eeuw een 'Kaiserlich-königliche Akademie der orientalischen Sprachen'. Dat wetenschappelijk instituut diende zeker ook de politiek, gezien de uitgebreide belangen van de Habsburgers op de Balkan, en hun contacten met het Ottomaanse Rijk. ${ }^{4}$

In Constantinopel vormen volgens de redactie de bibliotheken van Sultan Abdulhamid en van Raqib Pasja een 'Fundgrube'. Bovendien was Constantinopel de fysieke belichaming van het contact tussen Oost en West.

Ten slotte komen de redacteuren terug op hun ideële doelstellingen. In een passage vol metaforisch taalgebruik over mijnen en arbeid weiden zij uit over hetgeen 
mijnwerkers, die de schatten die zij ontdekken zuiveren, kunnen bijdragen aan de wereld. Het taalgebruik past goed in de Duitstalige romantische traditie. Zo worden ook in het dichtwerk van de oriëntaals-'angehauchte' Novalis veel mijnenmetaforen gebruikt. ${ }^{5}$ Tot dat doel mogen alle thema's in het tijdschrift worden aangeroerd, maar politieke en theologische discussies krijgen geen voorrang. Die vinden elders al hun forum.

Als het tijdschrift een publiek vindt, zal het 'das Neue, Wahre, Gute und Schöne des orientalischen Genius zu Tage fördern', belooft de redactie. Zo zal het 'Licht van het Oosten' zichtbaar worden 'nach dem so viele Augen sehnsuchtsvoll sich wenden'.

De Poolse magnaat Rzewusky mocht voor de financiering van het tijdschrift zorgen, hij was er niet de drijvende kracht achter. Dat was de jonge Oostenrijkse oriëntalistdiplomaat Joseph von Hammer, die een niet gering deel van de artikelen schreef. Hammer (1773-1856) nam circa eenzesde van alle bijdragen voor zijn rekening. Onderzoek naar zijn biografische gegevens levert ook meer details op over de onderneming die gerust de zijne genoemd mag worden. ${ }^{6}$

In 1808 keerde Hammer terug in Wenen, na een jarenlang verblijf als diplomaat in Constantinopel. Daar had hij veel geleerde medediplomaten leren kennen, waaronder de Russische gezant Italinsky, de Piëmontese ambassadeur Ludolf en een reeks oosters-bevlogen Engelsen. Omdat het diplomatiek bedrijf hem niet erg lag, zocht hij naar ander emplooi. In de salon van prins Lobkowitz ontmoette hij Rzewusky, die hij enthousiasmeerde voor de oosterse studies. Op driekoningenavond van het jaar I809, terwijl Napoleons legers de keizerlijke hoofdstad naderden, vond een banket plaats waar Rzewusky en twaalf geleerden de oprichting van de Fundgruben vierden. Onder hen was ook Friedrich Schlegel, die de Duitse fascinatie voor India belichaamde. Hammer bracht een toast uit op zijn oude vriend A.I. Silvestre de Sacy (1758-1838), de nestor van de Franse oriëntaalse studies die hij uit Constantinopel kende en die hij eerde als de 'grootmeester der Arabische grammatica'.

Als in de volgende dagen het hof uit Wenen vlucht, blijft Hammer achter. Hij voorkomt dat de totale collectie van oriëntaalse manuscripten uit de Hofburg geroofd wordt. In het najaar reist hij naar Parijs, om over de teruggave van de wel-ontvreemde teksten te onderhandelen. Hij hernieuwt er het contact met zijn vriend De Sacy, en leert ook de beide Humboldts kennen. Terug in Wenen bekleedt hij enkele ambtelijke functies, waaraan weinig werkzaamheden zijn verbonden, maar wel een salaris. Dit maakt het hem mogelijk om de oriëntalia van de Hofburg te gaan catalogiseren. In de zomers werkt hij aan zijn eigen onderzoek, in het buitenhuis van de Oriëntaalse Academie te Weidling. Zijn huwelijk, op 42-jarige leeftijd, met de achttienjarige bankiersdochter Karoline von Henikstein maakt hem financieel onafhankelijk. Hun huis wordt een literair-wetenschappelijk ontmoetingspunt, terwijl de goede reputatie van de Fundgruben Hammer ook internationaal aanzien bezorgt.

Hammers fascinatie voor het Arabische Oosten blijft groeien. Zoals later de ontdekking van India de Italiaanse oriëntalist De'Gubernatis ertoe brengt om de protagonisten uit deze oosterse cultuur in het Westen op het toneel te brengen, ${ }^{7}$ zo doet Hammer dat met de hoofdrolspelers uit het 'Arabisch drama'. In I8 33 schrijft hij een toneelstuk over een van de meest tot de verbeelding sprekende episodes uit de politieke geschiedenis van het kalifaat te Bagdad, de zogenaamde 'Val der Barmakieden'. In I 823 brengt hij zelfs 'Mohammed' op de planken, aangespoord door Mme 
De Staël, die hem aanmaande om de volgens haar inadequate verbeelding van Voltaire te overtreffen. ${ }^{8}$

Hammer voelt zich middelaar tussen Oost en West. Zo vertaalt hij de Meditationes van Marcus Aurelius in het Perzisch, om westers gedachtegoed aan het Oosten te schenken. Hammer - intussen door erfenis getooid met de naam Purgstall - verdiept zich echter steeds meer in de islamitische mystiek. Bij het overlijden van zijn echtgenote worden uit het Arabisch vertaalde gebeden gereciteerd en zijn eigen grafmonument is in geheel islamitische stijl ontworpen, met de gekalligrafeerde inscriptie 'Ich flog ins Morgenroth, Um aus zu ruhn in Gott.'

Hieronder staat een verdeling van de artikelen, die in de zes jaargangen verschenen, naar thema en naar de taal waarin zij gesteld zijn. Een snelle autopsie van de inhoud van de artikelen is moeilijk omdat veel auteurs zich niet duidelijk tot één thema kunnen of willen beperken. Bij de thematische verdeling is daarom besloten tot een overzicht van het gebied waarop de tekst betrekking heeft. Een werkelijke onderverdeling naar onderwerp zou verzanden in een te groot aantal categorieën.

TABEL I. SPREIDING DER BIJDRAGEN NAAR REGIO/THEMA

$\begin{array}{lr}\text { Oriënt algemeen } & 37 \\ \text { Arabisch/islamitische cultuur algemeen } & 88 \\ \text { Griekse cultuur } & 4 \\ \text { Osmaanse cultuur } & 53 \\ \text { Nabije Oosten } & 6 \\ \text { Egypte } & 12 \\ \text { Noord-Afrika } & 2 \\ \text { Abyssinië } & \mathrm{I} \\ \text { Midden-Oosten/Babylon } & 7 \\ \text { Perzische cultuur/Iran } & 9 \mathrm{I} \\ \text { (Perzisch-)Indiase cultuur } & 13 \\ \text { Centraal-Azië } & 12 \\ \text { China } & 3 \\ \text { Varia } & 4\end{array}$

TABEL II, SPREIDING DER BIJDRAGEN NAAR TAAL

$\begin{array}{lr}\text { Duits } & \text { I } 47 \\ \text { Frans } & 77 \\ \text { Latijn } & 32 \\ \text { Italiaans } & 2 \mathrm{I} \\ \text { Engels } & \mathrm{I} 7 \\ \text { Grieks } & \mathrm{I} \\ \text { Spaans } & \mathrm{I}\end{array}$

Wie de lezers van het tijdschrift waren is moeilijk te bepalen. In de eerste jaargang is een lijst van abonnees opgenomen. Ongetwijfeld dachten zij aan het tijdschrift een zeker aanzien te kunnen ontlenen. Wetenschap en cultuur verschaften tenslotte ook 
status. Onder hen bevinden zich een aardig aantal aristocraten uit de Habsburgse monarchieën en een hele reeks namen met een duidelijk Italiaanse, Griekse of Balkaneuze klank. Ook zij waren waarschijnlijk onderdanen van de Habsburgse keizer.

Aan het einde van de eerste jaargang worden in een nawoord wat zaken duidelijker. Allereerst beroemen de initiatiefnemers zich op het succes van de onderneming. Dat is op zich geen indicatie voor de werkelijke gang van zaken. Het ligt voor de hand dat het redactionele propaganda is. Wel is te constateren dat de animo om bij te dragen groot was. De eerste jaargang sloot af op meer dan vierhonderdvijftig pagina's, in plaats van op de begrote driehonderd. Volgens het nawoord waren veel artikelen afkomstig van vooraanstaande geleerden en verdienstelijke zakenmannen. Dat laatste was mogelijk een oratio pro domo, die beoogde een burgerlijk lezerspubliek te interesseren.

Aan het einde van de eerste jaargang traden een aantal redacteuren uit de anonimiteit. Wellicht is dat een aanwijzing dat het tijdschrift inderdaad begon te lopen. Behalve ene De Carro, medisch doctor, ${ }^{9}$ die voor de redactie van de Franse teksten tekende, en T. Chabert, hoogleraar oriëntaalse talen aan de Keizerlijke Academie, komt Hammer nu pas echt voor het voetlicht. Hammer, ooit Chaberts pupil, nam het leeuwendeel van de redactie op zich. Hij bestierde de bijdragen in het Duits, Engels en Latijn, en een deel van de teksten die uit de Oriënt zelf kwamen.

In de tweede jaargang, die pas in I8I verschijnt, komen nieuwe details aan het licht. De late verschijning wordt door de redactie geweten aan tijdgebrek in verband met drukke ambts- en andere bezigheden. Ook wordt de situatie van het boekenverkeer in de Duitse landen genoemd als oorzaak. Ongetwijfeld was dat het gevolg van de oorlogstoestand die de campagnes van Napoleon over heel Europa hadden uitgeroepen. Ten slotte verliep het ideeënverkeer met de overzeese wereld moeizaam, waarschijnlijk veroorzaakt door de continentale blokkade die de zeeweg naar delen van Azië afsloot, waaronder Engels-India.

Twee andere bijzonderheden springen in het oog. Allereerst de mededeling dat de aanvankelijke idee om het werkterrein van het tijdschrift tot heel Azië uit te breiden, weer is verlaten. De redactie wil zich beperken tot 'die orientalischen Sprachen im engsten Sinne', de Arabische, Perzische en Turkse talen en culturen. Niet iedereen was het eens met deze beperking. Zo benadrukte de Engelse geleerde Raynouard dat 'onze oriëntalisten, heel begrijpelijk, vooral India op het oog hebben'. ${ }^{\circ 0}$ De kwantitatieve data in tabel I, over de regio's waarop de artikelen betrekking hebben, suggereren dat de auteurs zich toch goeddeels hielden aan dat nieuwe uitgangspunt.

Een tweede punt betreft de traditie waarin de redactie het tijdschrift wenste te zien. De inleiding op de tweede jaargang bevat een forse uitweiding over het Concilie van Vienne (1311-I312), waar paus Clemens V zijn gehoor aanspoorde tot studie van het Arabisch, het Hebreeuws en het Chaldeeuws, en op die terreinen leerstoelen liet instellen aan de universiteiten van Bologna, Oxford, Parijs en Salamanca. Al in de veertiende eeuw bestond er dus oog voor de waarde van kennis over de Oriënt. De redactie stelde voldaan vast dat deze traditie nu in Wenen - het tweede Vienne - wordt voortgezet.

In het voorwoord van de derde jaargang, die keurig in $18 \mathrm{I} 3$ verschijnt, verheugen de redacteuren zich in een goede pers van Parijs tot Sint-Petersburg, dat als vestigingsplaats van de Russische Keizerlijke Academie van Wetenschappen al in de achttiende eeuw faam genoot als een centrum van met name de studie van Centraal- 
Azië." Financieel blijft het echter intussen behelpen. De vrijgevige mecenas Rzewusky is met het keizerlijke leger te velde, en heeft bovendien de grootste moeite met het beheer van zijn in bezet gebied gelegen goederen. Daar worden de inkomsten gegenereerd die in de ontginning van de Fundgruben worden gestoken.

De informatie die in het voorwoord van de vierde jaargang - anno I814 - naar buiten wordt gebracht is weer op andere wijze onthullend. Hoewel in Europa de oriëntaalse studies bloeien, doen zij dat toch vrijwel uitsluitend in Engeland en Frankrijk, constateert de redactie merkbaar mistroostig. De Duitse landen blijven daarbij ver achter, en in het noorden en zuiden van Europa gebeurt vrijwel niets. In retrospectief kan worden vastgesteld dat dit oordeel voor deze jaren juist was. Of de redactie zich van de oorzaken van deze situatie bewust was, is minder duidelijk. Zo constateerde zij dat alleen al in Calcutta - de hoofdstad van Engels Bengalen, waar de Royal Asiatic Society gevestigd was - meer gebeurde dan 'in de rest van de wereld'. Daar waren intussen de Shah-name en de Ramayana uitgegeven, en de teksten van Hariri. Opmerkelijk is dat de redactie in deze context niet refereert aan haar eigen besluit om de actieradius van het tijdschift nu juist niet in het Indiase cultuurgebied te leggen. Wel spreken zij over ondernemingen die inderdaad binnen het veld van de Fundgruben liggen. De Sacy zal zijn werk over de Druzen spoedig afronden, Wilken komt met een boek over de Kruistochten ${ }^{\text {t2 }}$ en Hammer met een studie over de Assassijnen en met een vierdelige editie van de reisverhalen van de Turkse geleerde Evliya. ${ }^{13}$ De redacteuren spreken ten slotte de hoop uit dat de vrede, die zich nu liet aanzien, ook het 'mijnwerk' zou versterken. Het geeft aan dat zij nog steeds in hun beeldspraak geloofden.

In I816, als de vijfde jaargang begint te verschijnen, is het eindelijk vrede. Volgens de redactie richt Europa de blik weer op het Oosten, de wieg en de kibla van de mensheid, de plaats waar religie en cultuur zijn ontstaan, het verloren paradijs. Opmerkelijk is dat de redacteuren, zij het impliciet, toegeven dat hun redactioneel standpunt van I8Ir niet was vol te houden. Steeds meer onderzoekers van Voor- en Midden-Azië vestigen hun aandacht op India waar de Britten, door een mengeling van Macht, Mässigung, und Genius 'veel groots kapot gemaakt, behouden, en geschapen hebben', een fraaie karakteristiek van het Britse koloniaal beleid.

De redacteuren van de Fundgruben moeten constateren dat Engeland de vergroting van zijn 'politieke en wetenschappelijke heerschappij' over India dankt aan de wederzijdse ondersteuning van diplomatie en talent. Edward Said zou in zijn handen klappen. ${ }^{14}$ De Britse regering ziet in dat alleen in de lokale talen en culturen geschoolde lieden de vergroting van het Brits domein en de kennis ervan kunnen dienen. De groeiende rol van de Britten in de oriëntaalse studies blijkt ook uit de eerste publicaties over Burma en Tibet, waar de Engelsen ook doordringen. Ook verhalen zij over hun ervaringen in Irak en Iran. Zo schenkt de redactie aandacht aan James Moriers reisbeschrijving van Perzië uit de beginjaren van de negentiende eeuw, die zij terecht de beste tot datum acht.

De artikelen in het tijdschrift zijn onder te verdelen in zes hoofdcategorieën. De hoofdmoot vormen tekstedities, wetenschappelijke beschouwingen, reisverslagen, artikelen die nieuw bronnenmateriaal in kaart brengen en recensies. Bovendien, en verrassend in een dergelijk periodiek, is er creatief literair werk. Veelal betreft het gedichten in oosterse talen, bijna altijd door westerse contribuanten gecomponeerd. Door deze literaire bijdragen onderscheidt het negentiende-eeuwse tijdschrift zich van de dodelijke saaiheid van het twintigste-eeuwse wetenschappelijke tijdschrift. 
De tekstedities

De eerste grote tekstedities in Fundgruben betreffen de basis van de islamitische traditie. Over enkele afleveringen verspreid publiceert Hammer bijna honderd pagina's uittreksels uit de Sunna, de mondelinge overlevering omtrent het leven van Mohammed. ${ }^{15}$ Deze worden later gevolgd door vele tientallen pagina's met berijmde vertalingen van alle hoofdstukken van de Koran. ${ }^{16}$ Ook verspreid over vele afleveringen treft men Hammers vertalingen uit Arabische kronieken aan die de Kruistochten vanuit islamitische blik belichten. Deze stukken sluiten duidelijk aan op de poging van het tijdschrift om een eenzijdig christelijk perspectief op de wereld van het Nabije Oosten te doorbreken. Hammer en anderen geven ook vertaalde uittreksels uit Ottomaanse kronieken. ${ }^{17}$

Eveneens opmerkelijk is de groeiende aandacht voor de 'Arabische' verteltraditie, al spoedig ook uitgebreid tot de Perzische wortels daarvan. Deze hield Europa in haar ban sedert de eerste Europese uitgave van de Verhalen van Duizend-en-Een-Nacht, door Antoine Galand in 1709 . Galands vertaling was echter intussen ontmaskerd als een vanuit wetenschappelijk oogpunt al te vrije bewerking. In dit kader past ongetwijfeld de bijdrage van de Engelse resident in Bagdad, J.C. Rich. De resident leverde het 'Verhaal van de zeven Slapers' in vertaling aan. ${ }^{18}$ Het tijdschrift brengt eveneens de verhalen van Djami, in zes langere bijdragen, onder de aandacht van de lezers. ${ }^{\text {t9 }}$

Vanuit de Perzische traditie draagt Silvestre de Sacy een omvangrijke reeks vertalingen bij van de Shah-name en de Pend-name, de hofkronieken van de Perzische heersers en van de Moghul-keizers van India. Daarnaast zijn de afleveringen doorspekt met vertalingen van Perzische gedichten, waarbij de poëzie van Saadi een duidelijke 'topper' is. Ook de korte gazals blijken populair. Deze werken boden vertaallustige oriëntalisten waarschijnlijk een goede oefengelegenheid.

De meeste tekstedities hebben betrekking op de cultuur van het 'Nabije Oosten'. Daarnaast legden de auteurs echter verbanden tussen de 'kernregio' van het tijdschrift en andere delen van het Oosten. Zoals eerder werd opgemerkt wordt er met name steeds meer betekenis gehecht aan de oude culturen van India. Een Deens oriëntalist draagt een Italiaanse vertaling bij van een van de purana's, uit de sanskritische Veda-traditie. ${ }^{20}$ Ook het grote hindoeïstische heldenepos, de Ramayana, komt althans ten dele in vertaling tot de Europese lezer. ${ }^{21}$ In de jaargang van I8I4 gaat het tijdschrift uitgebreid in op een rede die Lord Minto, de gouverneur-generaal van Brits-Indië, in 1813 hield voor de studenten van het Fort William College in Calcutta. Minto roemde het werk van de Britse bestuursambtenaren-oriëntalisten, met name Ch. Wilsons vertaling van de Meghaduta, de 'Wolkenboodschapper', het beroemde gedicht van de zesde-eeuwse schrijver Kalidasa. Deze schrijver, die al bekend was door de vertaling van zijn toneelstuk Sakuntala dat in de jaren negentig van de achttiende eeuw Europa had opgeschud, werd nu ook via de Fundgruben aan de lezers voorgesteld als een van de vaders van de Indo-Europese dichtkunst.

\section{De wetenschappelijke artikelen}

De tekstedities zijn indicatief voor de belangstelling van de redactie en de lezers van de Fundgruben. De wetenschappelijke artikelen geven echter een veel duidelijker beeld van de accenten daarin. Ook in deze artikelen besteden de auteurs aandacht aan de regio's buiten het Nabije Oosten.

Zo suggereert een lang artikel van U.J. von Seetzen (1767-I8II) in de eerste aflevering een vroeg contact met en beïnvloeding van Egypte door India en China, via de 
Zuid-Arabische wereld en Oost-Afrika. Dit contact zou hebben geresulteerd in de beschaving van Mozes en Pythagoras, kortom in de wortels van de Europese cultuur via de joodse en de Griekse tradities. Seetzen accepteert dus minstens impliciet het ouderdomsprimaat van de Zuid- en Oost-Aziatische culturen. ${ }^{22}$

Een andere bijdrage, over de oorsprong van de Europese cijfers, trekt eveneens lange lijnen door de Euraziatische cultuurgeschiedenis. Europa noemt de cijfers Arabisch, maar volgens de auteur van het artikel zouden ze echter in die vorm uit India stammen, en hun oorsprong waarschijnlijk in China hebben liggen. ${ }^{23}$ Op een dergelijke visie sluit een artikel aan van Dalberg. Deze auteur legt relaties tussen de Perzische mythologie en de varianten daarvan in enerzijds Scandinavië, en anderzijds India. ${ }^{24}$ Ook Egypte blijft fascineren, zoals blijkt uit een artikel van Hammer, dat aansluit op de discussie over de relaties tussen de Egyptische cultuur en de Griekse. ${ }^{25}$

In dit brede cultuurhistorische en -relativistische kader passen, dunkt mij, ook de bijdragen die zich bezighouden met de chronologie van de grote oosterse culturen. Zij moeten het de Europese wetenschap mogelijk maken de eigen cultuur niet alleen maar te duiden via onderzoek naar de transmissie van cultuur en ideeën, maar haar ook langs deze weg in een verantwoord tijdsperspectief te plaatsen. Zo gaat de sinoloog Klaproth uitgebreid in op Chinese inzichten in de geschiedenis van de mens vanaf de schepping ${ }^{26}$ en wordt aandacht besteed aan de eeuwigdurende kalender van de Turken. ${ }^{27}$

Het tijdschrift voorzag de vergelijkend-culturele beschouwingen van een kader door meer specifiek taalkundige studies te publiceren. Deze moesten de verwantschap tussen de talen van de Oriënt en de Occident aantonen. Dit wetenschapsgebied, nu Indo-Europeanistiek genoemd, had in de achttiende eeuw ook de aanzet gegeven tot meer omvattende, historisch-literaire en historisch-archeologische studies. Hoewel deze discipline in de eerste decennia van de negentiende eeuw juist ook in het Duitse cultuurgebied druk beoefend werd, is het aantal bijdragen eraan in de Fundgruben toch niet groot. Er was wel enige aandacht voor de Indo-Europese 'oertaal'. Zo schrijft de Franse sinoloog Abel-Remusat over de relatie tussen het Sanskriet en de talen van Oost-Azië en zijn er bijdragen over de relatie tussen het Perzisch en het Duits. ${ }^{28}$

Het aantal bijdragen op dit terrein mag dan niet omvangrijk zijn, de achterliggende ideeën zijn van het grootste belang. Dit blijkt uit enkele artikelen waarin de mogelijkheid om oosterse gedichten te vertalen gerelateerd wordt aan het grote probleem der taalverwantschap. Chabert poneert dat het Italiaans de taal is die zich het beste leent om het Perzisch in Europa te laten weerklinken. ${ }^{29}$ Hammer stelt daarentegen dat Duits en Engels daartoe beter geschikt zijn, omdat zij het meest aan het Perzisch verwant zijn. Het Duits zou zelfs beter zijn dan het Engels, aangezien het de meest zuivere Europese tak van die taal is..$^{30}$ Dit poogt hij later te verduidelijken door Firdusi's Shah-name $e^{31}$ te plaatsen naast het Nibelungenlied. ${ }^{32}$ Eenzelfde pretentie houdt hij hoog voor het Arabisch van, bijvoorbeeld, de Koran. Kortom, volgens Hammer is het Duits van alle Europese talen het meest geschikt om de lezer de Genius van de oosterse originelen te doen horen en voelen. ${ }^{33}$

De wijze waarop, en de mate waarin cultuurbeïnvloeding vanuit het Oosten naar het Westen plaatsgevonden had, stond ook in de belangstelling. Het tijdschrift belichtte de rol van het Iberisch schiereiland, ${ }^{34}$ maar ook de betekenis van een invloedrijk denker als Avicenna, de filosoof Ibn Sinna (980-1037) die via zijn commentaren bijgedragen had aan Europa's kennismaking met het gedachtegoed van Aristoteles en Plato. ${ }^{35}$ 
Hammer zelf gaat zijdelings in op het probleem van de cultuuroverdracht door aan te geven dat de 'oosterse' poëzie qua inhoud een belangrijke bijdrage geleverd heeft - en nog kan leveren - aan de Europese literatuur, maar dat aspecten van vorm en stijl toch beter getoetst kunnen worden aan, en eigenlijk ook voortkomen uit de Grieks-Romeinse traditie..$^{6}$ Elders verwijst hij naar de betekenis van de Arabische romances voor de Europese literatuur, via de Kruistochten. ${ }^{37}$

Van grote betekenis was ongetwijfeld ook een bijdrage over de noodzaak tot een gedegen Korankritiek, te koppelen aan een kritische analyse van de levens van Mohammed. Slechts door een dergelijke aanpak zouden wetenschappers kunnen vaststellen welke onderdelen van het Heilige Boek van de hand van de Profeet waren, en welke niet. ${ }^{38}$ Het is een duidelijke weerspiegeling van de wetenschappelijkempirische attitude die in de loop van de negentiende eeuw eveneens zou leiden tot de ontmythologisering van de persoon Jezus van Nazareth. Desalniettemin is het een werkwijze die, hoezeer ook in de christelijke wereld in ruime kring geaccepteerd, bijna tweehonderd jaar later in de islamitische wereld ook onder wetenschappers nog steeds zeer omstreden is.

\section{De reisverhalen}

Tekenend voor de betekenis van de reis en het reisverhaal in de wordende wetenschap van de oriëntalistiek is de eerste vermelding van het fenomeen in het tijdschrift. Voordat een zekere Ridder von Högelmüller op reis ging naar de Oriënt, vroeg hij de lezers van de Fundgruben om vragen. Uit zestien steden kwamen vragen binnen, van Madrid tot Trondheim, van Franeker tot Sint-Petersburg. Negenentwintig personen en instituten formuleerden zo'n 435 vragen. Het lijkt een wat bizarre realisering van de Europese vraagdrift die Bernardin de St Pierre in zijn novelle La chaumière indienne al in I79I aan de kaak gesteld had. Uiteindelijk ging de reis van Högelmüller niet door. ${ }^{39}$

Toch bleven de lezers niet verstoken van spannende avonturen. De eerste jaargangen van het tijdschrift staan vol met samenvattingen uit de reiservaringen van Seetzen, die in Afrika en op het Arabisch Schiereiland rondreisde, als hadzj-ganger vermomd..$^{\circ}$ Het relaas van zijn lotgevallen culmineerde in het verslag van zijn dood in I8I4 en de inbeslagname, door de heerser van Jemen, van zijn enorme collecties, maar liefst zeventien kameelladingen. Seetzen was immers een van die typische verzamelaar-reizigers die het hele Nabije Oosten afstroopte op zoek naar manuscripten, boeken, kunstvoorwerpen en naturalia..$^{47}$ Ook hij lijkt zo weggelopen uit de satire van De StPierre.

In andere teksten worden de voorbereidingen beschreven van een tocht naar de ruïnes van Palmyra die in I8Ig moest gaan plaatsvinden, en een verslag van Klaproths reis door de Kaukasus. Deze expeditie was onder meer bedoeld om materiaal te ontdekken dat licht kon werpen op de Perzische veldtochten tegen Peter de Grote in de vroege achttiende eeuw, en de gevolgen daarvan voor de Russische gebiedsuitbreiding in Centraal-Azië.42

Soms lijken de reisverhalen heel duidelijk met de contemporaine politiek verbonden. Een artikel over de Wahabiten, hun leiders en hun orthodox-islamitische ideeën hangt ongetwijfeld samen met de niet-uitgesproken vraag in welke mate zulke stromingen nu wel of niet de destabilisering van het Ottomaanse Rijk op het Arabisch schiereiland bevorderden en derhalve de mogelijkheden voor de Europese rol in het Nabije Oosten beïnvloedden. ${ }^{43}$ De idee dat de wetenschap zich buiten de politiek zou houden, verdedigd in het voorbericht tot het eerste nummer, werd dus niet altijd gerealiseerd. 
De archiefbesprekingen

Ongetwijfeld interessant voor de westerse wetenschappers die naar nieuw materiaal speurden waren twee omvangrijke bijdragen in de vierde jaargang. Hierin werden de handschriftelijke schatten beschreven van de Keizerlijke Bibliotheek in Wenen en de Engelse resident in Bagdad, J.C. Rich. Elders werd ingegaan op hetgeen in de Keizerlijke Bibliotheek te Sint-Petersburg berustte.

De recensies

Een vaste recensierubriek had het tijdschrift niet, in tegenstelling tot het latere Franse initiatief, de Journal Asiatique. Wellicht hing dit samen met de internationale situatie, die tot I8I4 geregeld boekenverkeer bemoeilijkte. Toch geeft in de eerste jaargang de Engelsman Reynouard een overzicht van min of meer recente titels, vooral uit het veld van de Engelse Sanskriet-studies..$^{44}$ Ook in latere afleveringen komen met regelmaat recensies voor, soms in de vorm van ingezonden brieven.

De eigen literaire bijdragen

Veel van het creatief-literaire werk staat in de traditie van de 'opdrachtgedichten' die al eeuwenlang de Europese boek- en tijdschriftcultuur karakteriseerde. Dikwijls betreft het in het Perzisch geschreven teksten die gebeurtenissen in het leven van de Rzewuskys luister bijzetten: het huwelijk van een dochter, de bouw van een landhuis, enzovoorts. ${ }^{45}$ De financier van de Fundgruben zal met deze publieke aandacht voor zijn mecenaat zeker verguld geweest zijn.

Bij de dood van een gravin Eszterhazy, geboren Von Metternich, verschijnt alweer een Perzisch vers, en de vertaling ervan. ${ }^{46}$ Hammer was de auteur van de meeste van deze gelegenheidsgedichten. Het was een genre dat hij ook in het origineel-Perzisch goed kende. Hij ontsloot voor de lezers van de Fundgruben de zogenaamde sherengis, gedichten die in islamitisch Iran gewijd werden aan beroemde, vooral schone mannen en vrouwen..$^{47}$ Geheel in stijl maakt hij ook zijn eigen leven tot thema van Perzische poëzie. Zo publiceerde hij een gedicht over zijn zoontje Karl. ${ }^{48}$

De zesde en laatste jaargang van het tijdschrift, die verscheen in I8I8, opende verrassend. Het voorwoord was niet in het Duits geschreven, maar in het Latijn. Het herdacht de strijd die de Tempelieren in de twaalfde eeuw gevoerd hadden met de Assassijnen. De ridderorde van de Tempelieren werd in IIIg opgericht in Jeruzalem, en had als doel de pelgrims in het Heilige Land te beschermen. De islamitische sekte van de Assassijnen, die zich met geweld en verraad verzette tegen de kruisvaarders in Palestina, was daarbij hun aartsvijand.

Op deze opening volgde een artikel dat beter een boek genoemd kan worden. In een bijdrage van honderdtwintig pagina's, eveneens in het Latijn, ging redacteur Hammer in op de invloed van het gedachtegoed van het Nabije Oosten op de Tempelieren. Hij was hiermee waarschijnlijk de eerste Europeaan die de complexe en zeer omstreden relaties tussen de ridderorde en de wereld van de Islam op een wetenschappelijk solide manier beschreef. ${ }^{49}$

Hammers artikel raakte een aantal gevoeligheden. Zijn interpretatie van de rol van de Tempelieren en hun mystiek en mysterieus gedachtegoed was nogal gunstig. Dat viel slecht in de christelijke wereld. In 1312 was de ridderorde immers opgeheven door paus Clemens V, na een proces waarin de Tempelieren waren beschuldigd van immoraliteit en ketterij. Hun grootmeester en veel ridders werden vervolgens in 
opdracht van koning Philips IV van Frankrijk levend verbrand. Het thema dat Hammer in zijn artikel aansneed, was voor veel Europeanen alleen bespreekbaar als de Tempelieren als ketters werden afgeschilderd. En dat deed de redacteur van de Fundgruben nadrukkelijk niet.

Heeft hij hiermee het doodvonnis van het tijdschrift getekend? Zeker is dat niet. Vast staat dat weinig wees op tanende vitaliteit. Ook deze jaargang bereikte vijfhonderd pagina's. Misschien hielden echter de Rzewusky-subsidies op en kon het drukken niet anders worden gefinancierd. Hoe dat ook zij, ik zoek een verklaring voor het vrij plotseling staken van de publicatie toch ook in de controversiële thematiek van Hammers artikel. Daarvan moet hijzelf als beste op de hoogte zijn geweest. Alleen al de voor hem ongebruikelijke keuze voor het Latijn duidde erop dat hij de stof van deze bijdrage niet wilde voorleggen aan een breed publiek.

In elk geval bleek uit een vijftig pagina's lange repliek in de zesde jaargang dat vele wetenschappers zich teweer gesteld hadden tegen zijn interpretatie..$^{50}$ Ook uit het milieu van de Vrijmetselarij was verzet gekomen - wellicht mede omdat Hammer zich afkerig getoond had van de snelle vermenigvuldiging van geheime genootschappen in zijn eigen tijd. Last but not least was er onrust in de kringen die begaan waren met de positie van het christendom in de Oriënt. Daarbij kan gedacht worden aan de regering in Wenen zelf, die natuurlijk haar politieke belangen had op de Balkan, in het oostelijke Middellandse-Zeegebied en in het Ottomaanse Rijk. Deze belangen waren zeker gediend met een goede verstandhouding met de Katholieke Kerk, in Rome, en in de Oriënt zelf.

Het was toen zoals het nu nog is. Zolang de wetenschap de politiek dient, is er niets aan de hand. Zodra de belangen echter botsen kan het mis gaan. Dat is mogelijk ook met de Fundgruben gebeurd. Een tijdschrift dat voor de heersende cultuur te brisante stellingen bevatte was men wellicht liever kwijt dan rijk. Het is enigszins navrant dat een periodiek dat blijkens de oorspronkelijke doelstelling de theologische discussie buiten de pagina's wilde houden, aan een religieus-politiek netelige zaak wellicht mede zijn ondergang te wijten heeft.

Intussen hadden echter velen uit de Fundgruben met kennelijke vreugde geput. Sommigen deden dat tongue in cheek, zoals de in de Fundgruben positief besproken Perzië-kenner James Morier. In I 824 publiceerde hij, schrijvend onder het 'pseudoniem' Peregrine Persic, zijn meteen bejubelde Perzisch-Europese satirische roman The Adventures of Hajji Baba of Ispahan in Londen. Morier droeg het boek quasi-serieus op aan de 'Aalmoezenier der Zweedse ambassade bij de Hoge Porte', die hij veelbetekenend de naam Dr. Fundgruben meegaf. ${ }^{51}$ Spotte hij zo met zijn eigen 'fans', en rekende hij onder hen ook de vroegere lezers van het tijdschrift? Behalve uit wetenschappers bestond de lezerskring in meerderheid waarschijnlijk uit de vele Europeanen die in toenemende mate door het 'exotische' Oosten gefascineerd waren. Niet de minste onder hen was Johann Wolfgang von Goethe, die ook naar eigen zeggen $^{52}$ voor zijn West-Östliche Divan zowel inspiratie als feitelijk materiaal had ontleend aan het vele dat de 'Mijnen van de Oriënt' hadden prijsgegeven.

-> PeTER Rietbergen is hoogleraar Expansiegeschiedenis aan de KU Nijmegen. Hij houdt zich vooral bezig met de geschiedenis van de culturele interactie tussen Europa en de niet-Europese wereld, en bestudeert mede in dat verband de cultuurgeschiedenis van Europa tussen de zeventiende en de late negentiende eeuw. 
* Met dank aan mijn collega Jan de Hond, voor kritiek en suggesties.

Daarbij laat ik buiten beschouwing de publicaties van de 'Asiatic Society of Bengal', gevestigd in Calcutta, waar vanaf de jaren tachtig van de achttiende eeuw 'proceedings' werden uitgegeven: de verhandelingen van dit genootschap werden ook in continentaal Europa veel gelezen, en vervulden, in zekere zin, de functie van een tijdschrift met artikelen.

2 Kennelijk bedoelt men het Archiv für Asiatische Literatur, Geschichte und Sprachkunde, waarvan slechts een aflevering te Sint-Petersburg werd gepubliceerd, in 1810 . J.H. Klaproth ( $1783-1835)$ was een sinoloog, die echter ook algemene studies betreffende (Centraal-)Azië publiceerde. en zich bezighield met het hiëroglyfenschrift.

3 Over Rzewusky is weinig te vinden. Het is mogelijk dat Les recits d'un vieux gentilhomme polonais (du Cte Rzewuski), die in 1866 in Franse vertaling te Parijs verschenen, zijn memoires behelzen.

4 Fundgruben, I, izo e.v. Voortaan citeer ik het tijdschrift slechts met jaargang en pagina. Om dezelfde reden floreerde overigens ook in SintPetersburg de studie van de oosterse talen. Zoals keizerlijk academicus Georgi aan de Fundgruben meldde, functioneerde de keizerlijke oriëntaalse drukkerij aldaar allereerst om de nieuwe stadhouderschappen in Ruslands groeiende Aziatische imperium van politiek-organisatorische teksten te voorzien en daarnaast om onderwijsmateriaal in het Turks, Tartaars, enzovoorts te drukken.

5 Cf. P.J. Rietbergen, "Een Europeaan droomt: Novalis tussen Europa, Christendom en Wereld', in: idem, Dromen van Europa, Amersfoort, 1993. $255^{-281}$.

6 De 'biografie' van B. Elgohary, Joseph Freiherr von Hammer-Purgstall (1774-1856): ein Dichter und Vermittler orientalischer Literatur, Stuttgart, 1979 , I92-220, gaat in op Hammers bemoeienis met de Fundgruben, maar geeft daarvan toch geen duidelijke analyse. Van betekenis voor Hammers denken en doen zijn zijn memoires: R. Bachoven von Echt, ed., Joseph von Hammer-Purgstall, Erinnerungen aus meinem Leben, 1774-1852, Wenen, 1940. Geciteerd als: EML.

7 P.J. Rietbergen, 'Naar de wortels van de Europese cultuur: Angelo de'Gubernatis (1840-1913) tussen Italië en India', in: Amore Romae, I, I997, 24-39.

8 EML, 183

9 Dit moet wel Jean de Carro, of Johann Carro (1770-1837) zijn, de arts die publiceerde over de koepokkenvaccinatie in het Osmaanse rijk.

10 II, 195, e.v.

II Cf. P.J. Rietbergen, 'Onderwijs en wetenschap als instrumenten van cultuurpolitiek: Rusland in de tweede helft van de zeventiende en de achttiende eeuw', in: Ex Tempore, II (1992), 32/2, I47-159.

12 Friedrich Wilken ( $1777-1840)$ was een historicus en iranoloog die inderdaad zijn werk, na decennia, voltooide: Geschichte der Kreuzzüge nach morgenländischen und abendländlichen Berichten, I-VII, Berlijn, I807-1832.

13 J. von Hammer, Narrative of travels in Europe, Asia and Africa, Londen, $1834-1850$, bevat de tekst van de Seyahat-name, het 'Boek der reizen' van de Turkse reiziger Evliya Celebi (1611-1675).

I4 Cf, P.J. Rietbergen, 'Oriëntalisme: een theorie van ficties - de fictie van een theorie? Een poging tot contextualisering en herinterpretatie', in: Tijdschrift voor Geschiedenis, III (I998), 545-575.

I5 $1,144-188 ; 277-316$

I6 II, 25-46; 336-358; III, 231-26I; IV, 68-86; 100-105.

I7 I, 3I6 e.v.; IV, passim.

I8 III, 347-38I.

$19 \mathrm{v}$, passim. Het gaat hier om het lyrisch werk van de Perzische dichter al-Jami (I414-I492).

20 II, 319-335.

$2 \mathrm{IV}, 188$ e.v.

22 1, 69 e.v.

23 II, 65 e.v.

24 I, 199 e.v.

$25 \mathrm{v}, 273-308$.

26 I, 428 e.v.

27 IV, passim.

28 vI, 162 e.v.; 390 e.v.

29 I, I8 e.v.

30 II, $42 \mathrm{I}$ e.v.; $\mathrm{Vl}, \mathrm{I} 62 \mathrm{e} . \mathrm{v}$

31 De Shah-name, ofwel het 'Boek der Koningen' is het werk van de Perzische historicus Firdusi (935-1020).

32 II, 422 e.v.

33 II, 26, e.v.

34 Bijv. 1,389 e.v.

35 Bijv. III, I68 e.v.: een korte biografische schets van Avicenna in het Frans.

$36 \quad 1,113$ e.v.

37 I, I4I e.v.

38 1, 129 e.v.

39 1, 457 e.v.

40 De tekst van het reisverhaal is later apart uitgegeven: Fr, Kruse, ed., Ulrich Jasper Seetzen's Reisen durch Syrien, et cetera, Berlijn, 1854-1859.

4 I Cf. U.J. von Seetzen, Verzeichnis des furr die orientalische Sammlung in Gotha zu Damask, Jerusalem [...] angekauften orientalischen Manuskripte und gedruckte Werke, Kunst- und Naturprodukte, Leipzig, I8ro.

42 vI, 349 e.v.

43 II, 155 e.v.

44 I, 274 e.v.

45 Bijv. II, 285 , enzovoorts.

46 VI, 402.

$47 \mathrm{~V}, 178 \mathrm{e}, \mathrm{v}$.

$48 \mathrm{~V}, 204$.

49 P. Ponsoye, L'slam et le Graal. Etude sur l'ésotérisme du Parzival de Wolfram von Eschenbach, Parijs, 1976, is zich van deze voor zijn thema belangrijke studie niet bewust.

50 VI, $445-499$

5I De connectie, en de grap ontgaan aan C.W. Stewart die in 1923 een heruitgave van Moriers roman bezorgde: $\mathrm{C} . \mathrm{W}$. Stewart, red, The Adventures of Hajji Baba of Ispahan by James Morier, Oxford, 1923. Wel geeft hij aan dat Morier in de tweede, herziene uitgave van zijn werk, in 1835 . de opdracht achterwege liet, met zoveel woorden omdat 'Dr. Fundgruben' zich liever niet meer in het openbaar genoemd zag: Stewart, op.cit., XIV. Had Hammer wellicht geprotesteerd?

52 Cf. I. Solbrig, Hammer-Purgstall und Goethe: 'Dem Zaubermeister das Werkzeug', Graz, 1973 